This work is licensed under a Creative Commons Attribution 4.0 International License.

Ovaj rad dostupan je za upotrebu pod licencom Creative Commons Imenovanje 4.0 međunarodna.

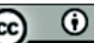

Tea DUZA

UDK 821.111(73).09 Carver, R.-32

Faculty of Philology "Blaže Koneski"

Ss. Cyril and Methodius University in Skopje

DOI: https://doi.org/10.29162/ANAFORA.v6i2.6

Miladin Popovikj 5/5, MK - 1000 Skopje

teaduza@yahoo.com

Pregledni članak

Review Article

Primljeno 16. travnja 2018.

Received: 16 April 2018

Prihvaćeno 3. prosinca 2018.

Accepted: 3 December 2018

\title{
THE ACCEPTANCE OF DEATH IN RAYMOND CARVER'S “A SMALL, GOOD THING”
}

\begin{abstract}
This paper discusses the ways Raymond Carver depicts death in one of his most well-known short stories "A Small, Good Thing." It deals with Carver's minimalism as a literary device used to portray the communication (or lack of it) between the characters. The paper may be divided into three parts, showing the different stages of dealing with the protagonist Scotty's death that his parents go through. The first part addresses denial, grief, and different ways in which people react to the death of a loved one. The second part elaborates on miscommunication as a leitmotif in Carver's stories and shows the complete breakage of communication between the characters; namely between Scotty's parents and the doctor, the baker, and the nurses, to name a few. The final part delves into the act of eating as a small, good gesture of kindness that brings people together and calms them down when a person dies. The end asserts that we constantly attempt to understand one another and, unfortunately, often fail to do so because of the unreliable and multi-faceted nature of language.

Keywords: Raymond Carver, death, acceptance, literature, minimalism, "A Small, Good Thing"
\end{abstract}


All literature somewhat orbits around death: from 74 onstage deaths in Shakespeare's complete works to the collection of Emily Dickinson's 1800 poems, which are all directly or indirectly connected with death, to Herman Melville's Moby Dick, which constantly reminds us that death lurks around each and every corner. Walter Benjamin, the renowned German literary critic and philosopher, has said that what we look for in literature (i.e. in fiction) is the knowledge of death that is denied to us in the real life. The dilemma that naturally arises from such a statement is: can literature help us accept or confront this most definite of all endings? (Benjamin, Bullock, and Jennings 1996).

Death is the greatest tragedy in life that nevertheless often brings people together and has the potential to connect and to console. In his Birth of Tragedy, Friedrich Nietzsche explores this idea of connectedness through suffering by looking at the reasons why ancient Greeks were so moved by tragic plays and concludes that tragedy emphasizes the sense of community by reminding people of unjustifiable ways the universe treats the individual (Nietzsche 1994).

With time, the topics that each literary period explores change (as well as the values of the readers), yet death as a theme, or a motif, is still an unfathomable abyss and it seems that it will continue to be. Even in recent times, modern and postmodern writers frequently present death as the ultimate dilemma that creates existential angst and dread because it offers an entrance to authentic self-discovery. In that sense, death is often seen as a step in the natural cycle of decay and renewal; or sometimes even dealt with as a reason for laughter, co-opted for humorous ends by writers of black comedy or absurdist drama. Despite the amount of lightness in such works, their writers are nevertheless fully aware of the seriousness of their subject.

In literature, the image of death carries a wide spectrum of symbolic interpretations that continue to gain new implications and connotations over the years. This is especially true when death connotes solipsism, estrangement, escapism and, ultimately, the essence of literature itself. Beginning with a brief exploration of Carver's minimalistic writing style to acquire a clearer image of his narrative techniques, the paper will try to delve into the ways in which we accept death by focusing on Raymond Carver's short story "A Small, Good Thing." 
What Carver achieved in prose resembles very much what William Carlos Williams achieved in poetry. He revived the American short story and was known for his dirty realism; prone to brevity and intensity, he focuses on mundane aspects of the middle-class life in simple and plain language. His writing style is commonly associated with Hemingway's although it might be argued that they represent different types of minimalism and that such a conclusion is based solely on their demonstration of an economical and bare prose style. The Hemingwayesque writing style was popular among Carver's generation of writers such as Donald Barthelme and Flannery O'Connor who, together with Carver, are considered to be the main pillars of the postmodern short story.

In addition to their style, Carver's short stories may be analyzed by using the Iceberg Theory (also known as "the Theory of Omission"). The term was coined by Hemingway and has been connected with his writing style ever since. The theory introduces the text as the tip of the iceberg, with the meaning, together with all the tensions and emotions, lying underneath. Needless repetitions and unnecessary information should be omitted. The writing style of the iceberg theory "suggests that a story's narrative and nuanced complexities, complete with symbolism, operate under the surface of the story itself" (Baker 117). Similarly, in Carver's stories, there is not much text on display, leaving much room for the reader to rebuild the emotions and create different shades of meaning - at least for the readers who want to use their imagination. Carver's titles are dubious, and his endings are particularly prone to various interpretations as he makes them enigmatic, sometimes even mildly surrealist. The lack of a specific setting implies that those stories can happen to anyone, anywhere. One of the most important elements in Carver's writing is his use of language, of which he claims the following:

It is possible, in a poem or a short story, to write about commonplace things and objects using commonplace but precise language, and to endow those things - a chair, a window curtain, a fork, a stone, a woman's earing - with immense, even startling power. It is possible to write a line of seemingly innocuous dialogue and have it send a chill along the reader's spine - the source or artistic delight, as Nabokov would have it. That is the kind of writing that most interests me. (Fires: Essays, Poems, Stories 28)

His language is also used to provoke misunderstandings and breakage of communication between the characters. He achieves this by subtly mentioning 
details that are seemingly intuitive and natural, yet delicate and emotionally charged. In "A Small, Good Thing," Ann, for example, bites her lips or clenches her fists when she is not able to articulate her emotions caused by her son's hospitalization.

To better understand the nuances in Carver's writing and his linguistic craftsmanship, a brief look at "A Small, Good Thing's" main plotlines is necessary. The story revolves around Scotty, an eight-year-old boy, who was injured in a hit-and-run accident on the day of his birthday. He is hospitalized the same afternoon, and from this point on the story turns into a gradual agony in which his parents' only hope is that he will soon recover. However, after a series of medical examinations, it appears that he is in a kind of coma - a medical condition that even the doctors seem to be unable to identify. Unfortunately, Scotty dies the minute after he wakes up (three days after his birthday) and leaves his parents shattered and devastated. The story features another plot about the baker who made Scotty's birthday cake. Ann, Scotty's mother, was supposed to pick up the cake before his birthday party, but due to the series of unfortunate events, she completely forgets about it. The baker keeps calling them while they are in the hospital with Scotty. These phone calls upset and distress them even more because they cannot remember who keeps calling them. After Scotty's death, his mother remembers about the cake and they hurry towards the bakery at midnight to ask the baker for an apology for his behavior. Nonetheless, after a short conversation with him, they seem to show empathy for each other's personal pain and at the very end of the story Scotty's parents eat at the bakery - they slowly calm down and accept the death of their child. "A Small, Good Thing" is thus a perceptive and complex psychological grief drama and its elegance is hidden in what resides under the seemingly simple surface common for Carver's prose: complex and universal emotions that even the most unobservant (or casual) reader could immediately identify and relate with. In his characters, Carver exposes numerous multi-faceted emotional nuances, tensions, and ill fortunes of a distressed middle-class.

Those multi-faceted emotional nuances and tensions climax in Carver's depictions of how Ann deals with her son's medical condition and death. At certain points, she is described as believing that she is the only one who suffers or that her husband is not as affected by their tragedy as she is: "For the first time, she felt they were together in it, this trouble. She realized with a start that, until now, it had only been happening to her and to Scotty. She hadn't let Howard 
into it, though he was there and needed all along. She felt glad to be his wife" (Cathedral 54). Up to that point, she could not understand her husband's way of grieving because it was not the same as hers, because it is usually difficult to show empathy for emotions that we have not experienced ourselves. Yet, Howard's fingers running through her hair and holding her shoulder as well as his confession that he has been praying for Scotty make Ann feel connected to him: "But they seemed to feel each other's insides now, as though the worry had made them transparent in a perfectly natural way" (Cathedral 57).

Carver's characters' near-inarticulateness in confrontation with the loss, in this case Ann and Howard's, has often been misunderstood as critics "who have scolded Carver for his minimalist shortcomings have done so for the same reasons that in previous generations they criticized Poe, Chekov, and Sherwood Anderson" (May 48). They point out that Carver's characters are too ordinary, unperceptive, and hopeless when confronted with difficult situations. Yet, contrary to that approach, we can maintain that Carver's texts exemplify how people living routine lives are closer to experiencing epiphanies when they are put under the pressure of unexpected situations - such as the death of a loved one.

Perhaps the most impressive and effective element in the story is Carver's mastery of poetic details. These details create an atmosphere of utter helplessness and weariness in which Ann and Howard are trapped. Time passes by linearly, yet slowly, one scene after another, and each of them is marked by a simple gesture of hope and pain: for example, Ann bites her lips while looking at Scotty, or clenches her fists out of anger, or feels pain just by having her husband's fingers on her shoulder. Howard also experiences similar moments:

Howard took the box out to the garage, where he saw the child's bicycle. He dropped the box and sat down on the pavement beside the bicycle. He took hold of the bicycle awkwardly so that it leaned against his chest. He held it, the rubber pedal sticking into his chest. He gave the wheel a turn. (Cathedral 61)

The passage is written in such detail that we can almost hear the sound the wheel makes when turned without moving the pedals. It is such an empty sound, and yet it resonates so powerfully with Howard's pain and suffering, especially if we have in mind that no one would ride the bicycle anymore. All these examples speak not only of a parent trying to come to terms with his child's death but also of Carver's art of subtlety in writing. 
Lastly, the story beautifully unites the paradoxical nature of being isolated in our own emotions and being connected in our loneliness: although Ann and Howard deal with Scotty's death in different ways and they may not directly recognize each other's manifestations of grief, their pain still connects and strengthens their relationship. In times like that, there is nothing more peaceful than knowing that we are not alone in our pain and suffering.

Carver's stories are further characterized by the complete breakdown of communication and miscommunication. He delves into linguistic nuances and discourses, showing how language can become an obstacle on an everyday basis as it simultaneously provides successful communication and limits our perception and thought. Carver's stories orbit around the impossibility of communication and expressing our feelings with thoughts, with "A Small, Good Thing" as a perfect example of it. Its characters lack the vocabulary that would mirror their emotions and try to express them through ambiguous, and at times even deranged, language. Ann, Howard, and even the baker, appear to be too tired to reach out to each other, even with language:

The baker was not jolly. There were no pleasantries between them, just the minimum exchange of words, the necessary information. ... You know what I mean, he [Howard] said. Juice, something. I don't know. I don't know anything, Ann. Jesus, I'm not hungry, either. Ann, it's hard to talk now. (Cathedral 49, 55)

Here Carver uses short and simple sentences, with noticeable repetitions and clean syntax. The dialogues are interrupted and filled with commonplace observations rather than emotions. This is thus where Carver's writing skill lies - he shows emotions by building up the atmosphere rather than by directly telling us how his characters feel. He is very picky with his words as the "fundamental accuracy of statement is the one sole morality of writing" (Pound 33). He uses what could be termed a cinematographic writing style: it is as if we are only given the stage directions to the characters - and it is our job to build their emotions while reading their lines.

Not only does Carver show his characters' emotions by building up the story's atmosphere but he also uses miscommunication to do it. One of them occurs when Scotty is carried down by the lift for some tests and Ann is also in the lift together with two orderlies who talk in a foreign language. The fact that she cannot understand what they are saying shows her inability to understand 
what is happening to her son. The doctors are not helping her either since none of them can tell what Scotty's diagnosis is: “No, I don't want to call it a coma,' the doctor said.... He's just in a very deep sleep"' (Cathedral 60). It looks as if he was trying to get away with it by using a euphemism that would not reflect the true nature of the medical condition. Another miscommunication in the story appears when the baker keeps phoning Ann and Howard to remind them of Scotty's cake. While Scotty is in the hospital, the phone rings five times and each call is more horrific than the previous one - creating tension, suspense, and disruption of the natural flow of events:

the telephone rang. She [Ann] picked it up on the first ring. "Hello," she said, and she heard something in the background, a humming noise. "Hello!" she said. "For God's sake," she said. "Who's this? What is it you want?" . . Much later just before midnight, . . the telephone rang again. "Hello," he said. "Who's this? Hello! Hello!" The line went dead. "He hung up," Howard said. "Whoever it was." (Cathedral 57, 63)

Foreshadowing is another technique Carver uses to build up the tension and create the gloomy atmosphere in the story. By depicting Ann having a brief conversation with the African American family whose son has been stabbed with a knife and dies soon after he is hospitalized, Carver uses their lack of words to express both their anger and their grief towards the condition of their children. It seems that language has completely failed to communicate the emptiness each of them feels - the emotional state that continues till the very end. The ending of the story is almost surreally sentimental. After they experience a whole range of negative emotions, "a breakdown of communication, such as avoidance of all discussion of the death or misunderstandings about it . . . [and] low intimacy" (Field and Behram 287), Ann and Howard confront the baker but they all end up sharing a similar stream of emotions. The baker calms them down and brings them comfort with his food and, in the end, they all empathize with one another through their shared feelings of agony and disappointment. Their epiphany, however, occurs once they start talking with the baker and hear his story. It seems that they all somewhat connect on an emotional level as they all share a similar feeling of disappointment with life. On the one hand, the baker has been baking cakes for birthdays, anniversaries, and all other happy occasions but he does not have children of his own for whom he could feel happy and share these festivities. He prepares food for occasions when families come together and celebrate but he has not taken part in such celebrations himself. He 
too had accepted the injustice and meaninglessness of life - his bakery appears to be the only constant in his life. Still, in the end, he connects with the grieving parents, for they too have lost their purpose in life after the death of their child. In a way, "A Small, Good Thing" introduces the reader to "an enlightening communal epiphany or collective cleansing that turns tragedy into Generativity ... a stage that can only be achieved by intimately embracing individuals on a familial, marital, and social level" (Bittlingmaier14).

What Carver might suggest with this story is that we are all connected in our smallness and lack of control over our lives. And even though it is impossible for us to ever truly understand one another, our efforts to be kind and understand are "a small, good thing" that make our transient lives worthwhile. One of those "small, good things" is food as well. The idea that food comforts us in times of pain and suffering has been a global tradition and an unwritten rule. In this way, the baker's warm hot rolls connect and comfort the three of them:

They [Ann and Howard] nodded when the baker began to speak of loneliness, and of the sense of doubt and limitation that had come to him in his middle years... They talked on into the early morning, the high, pale cast of light in the windows, and they did not think of leaving. (Cathedral 72).

Food has always been considered a crucial part of funeral traditions; and although different cultures have different rituals connected with food, its purpose has always been the same: to connect and to create a safe and warm atmosphere in which people will forget death. In "A Small, Good Thing," both Scotty's parents and the baker find comfort and peace in the cozy bakery and with this Carver ends the story in a positive tone that promises a slow but steady reconciliation with life. In it, Carver subtly shows a range of emotions - from anger to grief to helplessness (or meaninglessness) - and all of them are in relation to the death of a loved one.

Carver's craftsmanship "tends towards dramatic monologue, present-tense soliloquy that wears the past like a hair shirt" (Longley 23). It lies in his ability to capture emotions that each of us has felt at a particular time in our lives, such as denial, grief, meaninglessness (and absurdity) of life, (mis)communication and linguistic limitations, but also simple gestures of kindness that have drastically changed the course of actions for the better. Kindness also lies in words and as Carver himself states: "That's all we have, finally, the words, and they had better 
be the right ones, with the punctuation in the right places so that they can best say what they are meant to say" (Fires: Essays, Poems, Stories 58).

\section{Works Cited}

Baker, Carlos. Hemingway: The Writer as Artist. Princeton UP, 1972.

Benjamin, Walter. Walter Benjamin: Selected Writings, Volume 1: 1913-1926, edited by Marcus Bullock and Michael W. Jennings, Belknap Press, 1996.

Bittlingmaier, Michael J. Raymond Carver and the Menacing Search for Identity and Intimacy. State University of New York College at Brockport, Department of English, Digital Commons @Brockport, 2005.

Browning, Robert. Men and Women. El Paso Norte Press, 2009.

Carver, Raymond. Cathedral. Vintage Classics, 1983.

---. Fires: Essays, Poems, Stories. Vintage Books: A Division of Penguin Random House LLC., 1989.

Donne, John. "Holy Sonnets." The Collected Poems of John Donne. Wordsworth Editions Ltd., 1999, p. 128.

Field, Marilyn J., and Richard E. Behram. When Children Die: Improving Palliative and Endof-Life Care for Children and Their Families. National Academies Press, 2003, https:// www.ncbi.nlm.nih.gov/books/NBK220798/. Accessed 10 Feb. 2018.

Longley, Edna. "What the Doctor Said." London Review of Books, vol. 12, no. 6, 1990, pp. $22-23$.

May, Charles E. 'Do You See What I'm Saying?': The Inadequacy of Explanation and the Uses of Story in the Short Fiction of Raymond Carver." Yearbook of English Studies, vol. 31, 2001, pp. 39-49.

Nietzsche, Friedrich. The Birth of Tragedy. Penguin Classics, 1994.

Pound, Ezra. Pound/Joyce: The Letters of Ezra Pound to James Joyce. New Directions Publishing, 1967. 


\title{
PRIHVAĆANJE SMRTI U PRIPOVIJETCI „MALA DOBRA STVAR“ RAYMONDA CARVERA
}

\begin{abstract}
Sažetak
Tea DUZA

Filološki fakultet "Blaže Koneski”

Sveučilišta svetih Ćirila i Metoda u Skopju

Ulica Miladina Popovikja 5/5, MK - 1000 Skopje

teaduza@yahoo.com
\end{abstract}

Ovaj rad analizira načine prihvaćanja smrti u jednoj od najpoznatijih pripovijedaka Raymonda Carvera „Mala dobra stvar“, s posebnim osvrtom na Carverov minimalizam kao književno sredstvo prikaza komunikacije (ili njezina nedostatka) među likovima. Rad se može podijeliti na tri dijela od kojih svaki prikazuje različite razine prihvaćanja smrti djeteta kroz koje prolaze Scottyjevi roditelji. Prvi se dio bavi poricanjem, tugom i drugim osjećajima kao reakcijama na smrt voljene osobe. Drugi dio analizira pogrešan način komunikacije kao lajtmotiv u Carverovim pripovijetkama te ga pronalazi u potpunom prekidu komunikacije među likovima pripovijetke - Scottyjevim roditeljima i liječnikom, pekarom, medicinskim sestrama i dr. Posljednji dio iščitava čin jedenja kao malu dobru gestu ljubaznosti koja povezuje ljude te ih smiruje kad voljena osoba umre. Rad završava zaključkom kako neprestano pokušavamo razumjeti jedni druge premda to nažalost često ne uspijevamo zbog nepouzdane i raznolike prirode jezika.

Ključne riječi: Raymond Carver, smrt, prihvaćanje, književnost, minimalizam, „Mala dobra stvar" 